\title{
Coordination of Regional Disaster Management Agencies In Providing Logistics and Disaster Management Equipment In Gunung Mas District, Central of Kalimantan
}

\author{
Iputrajaya $^{1}$, Andi Tenri Sompa ${ }^{1}$, Jamaluddin ${ }^{1}$ \\ ${ }^{1}$,Lambung Mangkurat University, Indonesia
}

Received: 3 March 2021

Article Info

Accepted: 28 March $2021 \quad$ Published: 9 April 2021

\begin{abstract}
Keywords:
Coordination

Logistic

Equipment

BPBD

Gunung Mas Regency
\end{abstract}

\section{Copyright and License:}

Authors retain copyright and grant the journal right of first publication with the work simultaneously licensed under a Creative Commons Attribution 4.0 International License that allows others to share the work with an acknowledgment of the work's authorship and initial publication in this journal. 


\section{INTRODUCTION}

The Gunung Mas District Disaster Management Agency (BPBD) is an element supporting the duties of the Regent in implementing disaster management, and is the leading sector for disaster, led by the Regional Secretary (Sekda) who functions as ex-officio and for operational activities carried out by a Head. Implementing Agency that is under and directly responsible to the Regent. The Regional Disaster Management Agency has the task of establishing guidelines and directions for disaster management consisting of disaster prevention, emergency response, rehabilitation, reconstruction fairly and equitably as well as standardizing needs and informing disaster-prone maps based on disaster management SOPs, reporting on the implementation of disaster management to The Regional Head is once a month in normal conditions and in a state of disaster emergency and is accountable for the use of the Regional Budget [Gunung Mas Regency Regional Regulation Number: 8 of 2008 concerning Organization and Working Procedures of the Regional Disaster Management Agency of Gunung Mas Regency].

In carrying out the tasks referred to inabag, the Regional Disaster Management Agency of Gunung Mas Regency has the function of formulating and stipulating disaster management policies in handling refugees by acting quickly and appropriately and effectively and efficiently and coordinating the implementation of disaster management activities in a planned, integrated manner, and thorough [Peraturan Kepala BNPB Nomor 4 Tahun 2008 Tentang Perencanaan Penanggulangan Bencana].

The RegionalManagement DisasterAgency of Gunung Mas Regency has the primary task and function of overcoming various kinds of disasters, especially in the framework of coordinating the provision and distribution of logistics and equipment during disasters and post-disaster. Because at this time, the coordination formed still has several weaknesses and shortcomings as well as still ineffective so that there is still a wrong target in terms of distribution and distribution to the affected community. Each agency or other institution was distributing logistical assistance and equipment to the community independently without any integrated coordination resulting in accumulation in one place. One example that became a problem was in 2017, wherein the distribution of logistics and disaster management equipment there was no integrated and effective coordination due to sectoral ego to the. Design ate right that so it becomes a problem in itself and of course it must immediately fixed. The coordination carried out by the Gunung Mas District Disaster Management Agency in the distribution of logistics and equipment is an opportunity to implement policies, strategies and operations for disaster management as an integrated and systemic movement and one command.

The Regional Disaster Management Agency of Gunung Mas Regency under the mandate of the Laws and Regional Regulations is an agency appointed by the regional government to deal with various disaster problems that occur from before the occurrence of a disaster, when the disaster occurs or after the disaster. Pre-disaster coordination requires a unified concept of action. With the existence of a mutually agreed-upon unit of action, the Regional Disaster Management Agency as the agency has the authority at this stage can divide tasks between agencies invited to collaborate. Thus the desired objectives can be achieved in this pre-disaster stage with coordination in providing information and sharing.

The precise and directed coordination carried out by the Gunung Mas Regional Disaster Management Agency for other related agencies and institutions in terms of flood disaster 
management and can ensure adequate logistical assistance and equipment for disaster victims can be provided on time, on location, on target, quality and quantity as well as ensuring the distribution of other special needs to residents experiencing the flood disaster. The conditions as mentioned above indicate that the current coordination between agencies/institutions, especially during disasters, especially floods and landslides, is still lacking in synergy in terms of disaster management, especially in the distribution of logistical assistance and equipment to the community.

According to GR Terry said that coordination is an orderly synchronization of efforts to create time management that is guided in the results of a harmonious and unified implementation to achieve predetermined goals. Coordination is also a collaborative effort between units or units that are separate from an organization to create unity in achieving the goals set by unifying activities to achieve harmony in carrying out tasks to achieve common goals effectively and efficiently [Terry, 2006] Based on the background of these problems. The authors are interested in researching the Coordination of Regional Disaster Management Agencies in the Provision of Logistics and Disaster Management Equipment in Gunung Mas Regency, Central Kalimantan Province.

\section{METHODOLOGY}

The research approach used is qualitative. Which is an attempt to reveal a problem, state or condition as it happens so that research reveals facts and provides an objective picture of the actual state of the object under study and puts forward the process of deep communication interaction. The qualitative descriptive approach used so that the research carried out is more focused and by the objectives expected by the researcher. According to Bogdan and Taylor (Moleong, 2007), the qualitative method is a research procedure that produces descriptive data in the form of written or spoken words from the people and the behaviour being studied or observed. The type of this research is descriptive qualitative - this research intended to reveal problems or phenomena that occur by providing an accurate description of the actual conditions. The location of this research is the Regional Disaster Management Agency of Gunung Mas Regency, Central Kalimantan Province. Determining the location of this study aims to limit the scope of the research and the problems under study. The data collection techniques used in this study are non-involved observation or observation, unstructured interviews and documentation.

The primary informants for the study consisted of the Head of the Regional Disaster Management Agency for Gunung Mas Regency, the Head of Emergency and Logistics at the Regional Disaster Management Agency of Gunung Mas Regency. Besides, other research informants were also from the Head of the Logistics Section at the Gunung Mas Regional Disaster Management Agency and the Head of the Social Protection Section for Natural Disaster Victims and Social Protection for Social Disaster Victims at the Gunung Mas District Social Service.

\section{FINDINGS AND DISCUSSION}

BNPB Regulation No. 3 of 2008 concerning the formation of the BPBD in which the regulation states that the BPBD must coordinate horizontally with related agencies. Also, BNPB Regulation No. 4 of 2008 concerning disaster management planning that to cope with disasters, external coordination is carried out between related agencies/institutions both from the government sector and from the private sector. Private sector namely the Health Service, Social Service, Environmental Service, TNI, POLRI, Tagana, Scouts and District Volunteers. 


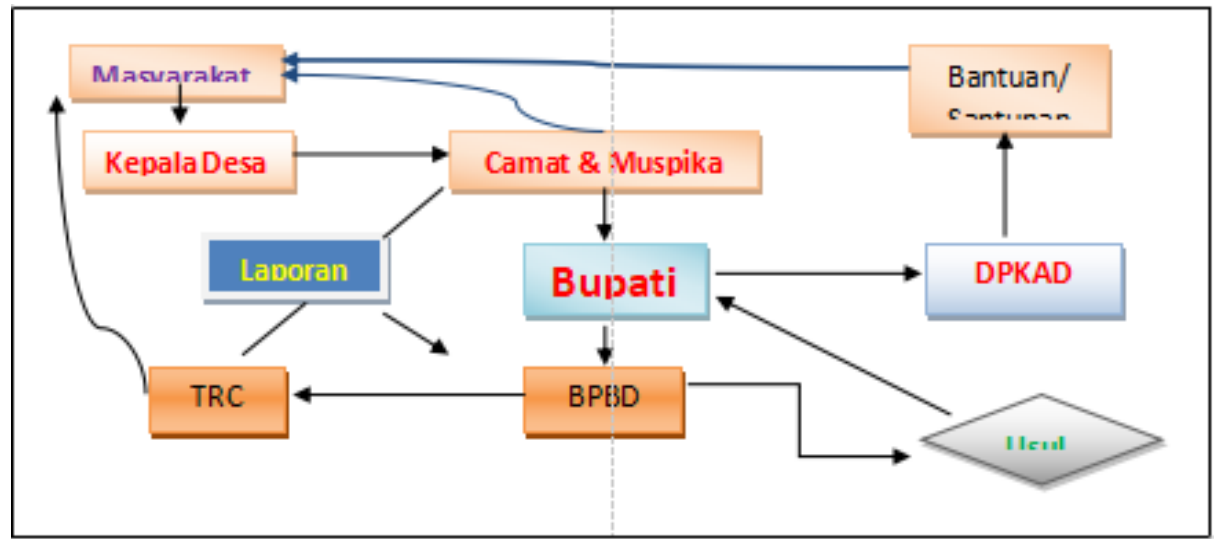

Figure 1. Assistance Distribution Based on SOP BPBD

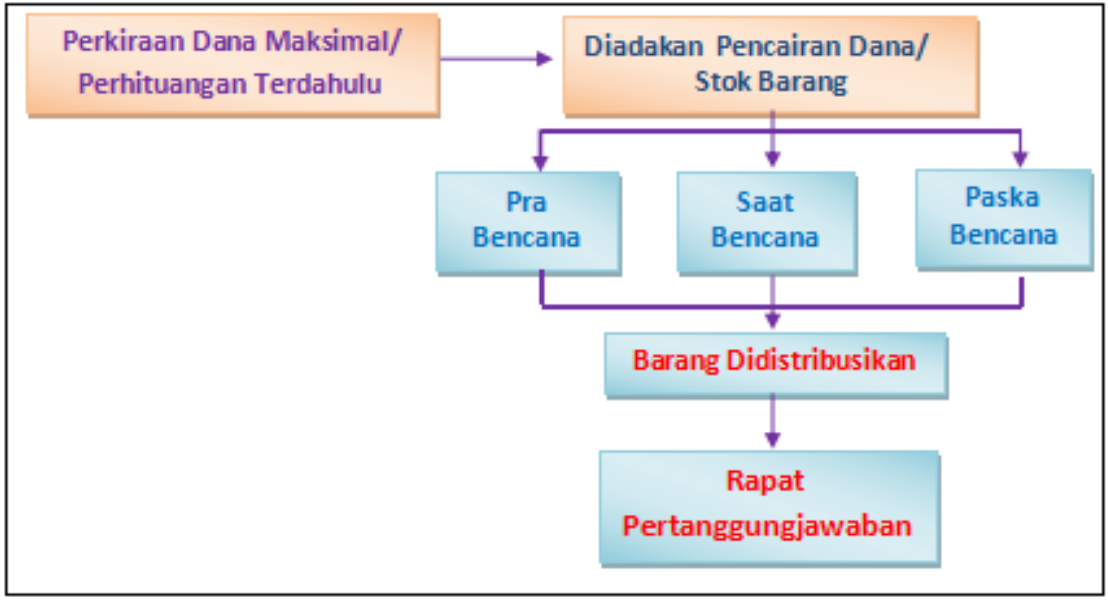

Figure 2. Process of Designing a BPBD Assistance Distribution Mechanism

In the implementation of the duties of the Gunung Mas District Disaster Management Agency, it has the following functions:

1. Formulation and determination of policies for disaster management and handling of refugees by acting quickly and appropriately, effective and efficient;

2. Coordinating the implementation of disaster management activities in a planned, integrated and comprehensive manner;

3. The implementation of others by his duties and functions.

Coordination is one of the functional tasks of the Gunung Mas District Disaster Management Agency in terms of providing logistics and equipment for disaster management in Gunung Mas Regency. Disaster emergency response status issued through the Gunung Mas Regent Decree Number: 405 of 2017 concerning Determination of Emergency Response Status for Flood and Landslide Disaster Management in Gunung Mas Regency in 2017. In this regulation, it regulates inter-sectoral coordination / related institutions for the achievement of objectives which will be determined jointly in the handling of disasters that occur in the Gunung Mas District.

Regional Disaster Management Agency which is a supporting element in disaster management for the provision of logistics and equipment which should be coordinated effectively, harmoniously and synchronously among other institutions. It is essential in regional disaster management so that there is no overlap in the provision of logistics and equipment due to a lack of coordination. Coordination between related institutions is carried out by the Gunung Mas District Disaster Management Agency, especially the Gunung Mas District Social Service, which also has a disaster 
management function in terms of providing logistics for victims of natural disasters and social disasters. Coordination for the provision of logistics and equipment has aligned with the Social Service, which has tasks in disaster management, namely the provision of basic foodstuffs for disaster victims, namely rice. At the same time, the Gunung Mas District Disaster Management Agency will provide other necessities except for rice because they have provided by the Social Service. that is, to deal with disaster events effectively in terms of providing logistics and equipment.

The determination of the types of staple foods to be distributed to victims of natural disasters and non-natural the result of good coordination that has been carried out by the Gunung Mas District Disaster Management Agency with the Gunung Mas Regency Social Service because they have almost the same function, although it only exists in one sub-field. Types and quantities of basic necessities provided by the Management Gunung Mas District Disaster Agency, Gunung Mas District Social Service, 2019 National Disaster Management Agency.

Table 1. Types of logistic packages distributed to residents experiencing floods in Gunung Regency Mas.

\begin{tabular}{|c|c|c|c|c|}
\hline No. & Name Type Item & Number Item & Help Resources & Year \\
\hline 1. & Rice & $4,332 \mathrm{Kg}$ & Budgets (Social Service) & 2019 \\
\hline 2. & Fast Food & $4332 \mathrm{Pcs}$ & Budget (BNPB Center) & 2019 \\
\hline 3. & Sugar & $4332 \mathrm{Kg}$ & Budgets (BPBDs \& DPKA) & 2019 \\
\hline 4. & Instant Fried Noodle & $21.660 \mathrm{Pcs}$ & Budgets (BPBDs \& DPKA) & 2019 \\
\hline 5. & Milk & 4332 Pcs & Budget (BPBDs \& DPKA) & 2019 \\
\hline 6. & Edible Oil & $4332 \mathrm{Ltr}$ & Budgets (BPBDs \& DPKA) & 2019 \\
\hline 7. & Sardine Yamato & $21.660 \mathrm{Pcs}$ & Budget ( BPBDs \& DPKA) & 2019 \\
\hline 8. & Tea Sariwangi & $4332 \mathrm{Pcs}$ & Budget (BPBDs \& DPKA) & 2019 \\
\hline 9. & Coffee & $4332 \mathrm{Pcs}$ & Budget (BPBDs \& DPKA) & 2019 \\
\hline 10. & ABC Ketchup & 4332 Pcs & Budgets (BPBDs \& DPKA) & 2019 \\
\hline & Total & 77,976 & - & - \\
\hline
\end{tabular}

The data from the table above, it seen that the provision of logistics and equipment in regional disaster management comes from the Social Service APBD, BPBD APBD and DPKA APBD, and the Central BNPB APBN. Coordination of Regional Disaster Management Agencies in Provision of Logistics and Equipment for Disaster Management in Gunung Mas District, Central Kalimantan Province. In the Head of BNPB Regulation No. 3 of 2008 concerning the formation of $\mathrm{BPBD}$ in which the regulation states that BPBD must coordinate with agencies/service agencies horizontally. The Head of BNPB Regulation No. 4 of 2008 concerning disaster management planning that to cope with disasters, external coordination is carried out between related agencies/institutions both from the government sector and from the private sector, namely the Health Service, Social Service, Environmental Service, TNI, POLRI, Tagana, Scouts and District Volunteers.

The Regional Disaster Management Agency of Gunung Mas Regency is an element supporting the duties of the Gunung Mas Regent in organizing the Regional Government in the Disaster 
Management Sector which is led by a Head of the Agency who is under and directly responsible to the Gunung Mas Regent. In carrying out the duties of the Gunung Mas District Disaster Management Agency, it has Functional Tasks, namely:

1. Formulation and stipulation of policies for disaster management and handling of refugees by acting quickly and precisely, effectively and efficiently;

2. Coordinating the implementation of disaster management activities in a planned, integrated and comprehensive manner;

3. Implementation of other duties assigned by the Regent following his duties and functions;

The coordination carried out by the Regional Disaster Management Agency of Gunung Mas Regency in handling disasters that occurred in the Gunung Mas Regency in the provision and distribution of logistics and equipment for victims of natural disasters, and non-natural disasters must be carried out across sectors/institutions to achieve the objectives that have been set in a manner, fast and precise, effective and efficient. The coordination that is carried out by the Gunung Mas District Disaster Management Agency is to provide logistics and equipment with the Gunung Mas District Social Service because each of these agencies has the same function in providing logistics and equipment for victims of natural disasters and victims of social disasters.

Based on the research that has been carried out, then the research data obtained is intended to determine the coordination of the Regional Disaster Management Agency in the context of providing Disaster Management Logistics and Equipment in Gunung Mas Regency. This coordination includes coordination elements, namely regulation, synchronization, shared interests and common goals. The coordination that is carried out in terms of providing logistics and equipment for disaster management in Gunung Mas Regency intended so that the disaster management can handled effectively and efficiently, planned, integrated and thoroughly so that the objectives can be maximally achieved.

However, it needs to be emphasized by the researcher that the coordination in question is not general, because it is only coordination in terms of providing logistics and equipment, meaning that coordination is only the provision of logistics and equipment in disaster management in Gunung Mas Regency and does not constitute overall coordination and coordination in this area. Emphasizes on the system of time management and timeliness in coordination, synchronization and harmonization in coordination, common interests to be achieved in coordination and common goals agreed upon in coordination. The coordinated institutions are institutions or institutions that have a relationship in disaster management, namely between the Gunung Mas District Disaster Management Agency and the Gunung Mas District Social Service, and researchers only research at the Gunung Mas Regency Regional Disaster Management Agency in the field of Logistics and Emergency and Logistics SubSector and Social Service in the Social Protection Section of Gunung Mas Regency which carries out main functions in regional disaster management, one of which is in the provision of logistics and equipment.

According to Inu Kencana Syafiie (2011: 85) says that coordination is the adjustment of each part, and efforts to move and operate the parts at the right time so that each part can contribute the most to the overall result so that The coordination elements that must exist are regulation, synchronization, shared interests and common goals. Furthermore, we will discuss research findings with the theories that have developed in the previous chapter.

\section{Arrangements}

Finding the field indicate that providing logistics and equipment for disaster management is the duty of the agency RegionalManagementfor Disasterthe Gunung Mas Regency, Logistics SubSector in accordance with the job descriptions described in the previous chapter, one of which is to 
coordinate the implementation of disaster management activities, planned, integrated and comprehensive. The coordination carried out by the Gunung Mas Regional Disaster Management Agency with other related institutions, one of which is the Social Service, starting from pre-disaster, emergency response and post-disaster both natural disasters and non-natural disasters in the Gunung Mas Regency Area. Timing and timeliness in coordination carried out by the Regional Disaster Management Agency of Gunung Mas Regency are adjusted to the conditions and situations and weather in Gunung Mas Regency.

The findings also show that the provision of logistics and equipment for disaster victims has been adjusted according to the type of disaster that occurred. The timeliness and timing of coordination have had a significant impact on the success of disaster management in the Gunung Mas Regency area because they have been formulated and determined and adjusted to the existing situation and circumstances. From the results of interviews and documentation studies it is known that the basis for the Gunung Mas District Disaster Management Agency in coordinating with other related institutions or as a coordination guide is contained in Law No. 24 of 2007 article 7 states that the Regional Disaster Management Agency performs the function of coordinating the implementation of disaster management activities in a planned, integrated and comprehensive manner and is strengthened by the Regulation of the Head of the National Disaster Management Agency No. 3 of 2008 concerning the Establishment of RegionalManagement DisasterAgencies which states that Regional Disaster Management Agencies must coordinate with other agencies / agencies horizontally at the pre-disaster, emergency response and post-disaster stages and Regulation of the Head of the National Disaster Management Agency No. 4 of 2008 that in order to cope with disasters ,carried out external coordination is between related agencies / institutions in several government sectors, including the Health Service, Social Service, Environment Service, TNI, POLRI, Tagana, Scouts and other volunteers.

Based on research from the results of interviews, coordination with other institutions/agencies related to regional disaster management refers to the coordination process during pre-disaster, emergency response and post-disaster as well as coordination during the process of making essential decisions in disaster management so that the coordination process for disaster management is planned, integrated and comprehensive in disaster management, especially in the provision of logistics and equipment when a disaster occurs. Leonard D White in the book Inu Kencana Syafii (2011: 33) says that coordination is the adjustment of each part, and efforts to move and operate the parts at the right time so that each section can contribute the most to the overall result.

Coordination in terms of guided time management is carried out according to time and right and has been based on applicable regulations and also following the theory put forward that coordination is carried out in regional disaster management in the provision of logistics and equipment. For disaster victims, coordination has been carried out with appropriate and appropriate time arrangements in accordance with the conditions and situations and weather in the Gunung Mas Regency Area. Based on research from the results of interviews, the coordination carried out by the RegionalManagement DisasterAgency of Gunung Mas Regency, especially coordination with the Gunung Mas Regency Social Service, namely during Pre-Disaster or before a disaster, Emergency Response or during a disaster and Post-disaster or after a disaster occurs as well as coordination carried out, namely in a tiered manner involving elements of regional leadership.

It is further clarified by the theory presented by Awaluddin Djamin in Hasibuan (2011: 86) that coordination is defined as an effort to cooperate between agencies, agencies, units in the implementation of specific tasks so that there is complementarity, mutual help and complementarity. Thus coordination by the Management Gunung Mas District DisasterAgency is an effort capable of harmonizing the implementation of the duties and activities of the Gunung Mas District Disaster 
Management Agency with the Social Service so that each of these agencies has one common goal in an organization and coordination will become priority will be other institutions.

\section{Synchronization}

Based on research and interview results and data obtained that synchronization of coordination in management disaster in Gunung Mas Regency has been running according to the opinion expressed by Awaluddin Djamin in Hasibuan (2011: 86) coordination is an effort of cooperation between agencies. , agencies, units in carrying out specific tasks, so that there is complementarity, mutual help and complementarity. Thus coordination can be interpreted as an effort that is able to harmonize the implementation of tasks and activities in an organization so that it runs simultaneously and sequentially. Based on research from the results of interviews, the alignment or synchronization of coordination in disaster management in Gunung Mas Regency in terms of providing and distributing logistics and equipment for disaster victims has been running in an orderly, regular, harmonious and guided manner and is available and channelled effectively and efficiently, and there is no overlap in this matter so that the stated objectives can be achieved optimally.

Coordination for the provision of logistics and equipment has been aligned with the Social Service, which has tasks in disaster management, namely the provision of basic foodstuffs for disaster victims, namely rice. At the same time, the Gunung Mas District Disaster Management Agency will provide other necessities except for rice because they have been provided by the Social Service. that is, to deal with disaster events effectively in terms of providing logistics and equipment. The results of the interview also revealed that coordination in disaster management in the Gunung Mas Regency area with the Social Service could run effectively and efficiently because each of these Agencies has harmony and understanding as well as the same goals so as not to overlap the work of providing and distributing logistics and equipment and synchronization in the coordination or alignment of various parties or other related institutions/agencies have been running orderly and regularly and this is in Ndraha's opinion in his book Kybernology (2003: 291) that coordination is a process of collective agreement binding various activities or elements, which vary in such a way that on the one hand all activities or elements are directed at achieving a goal predetermined.

Based on the results of interviews, the coordination carried out by the Management Gunung Mas Regional DisasterAgency with other agencies/agencies, especially the Gunung Mas District Social Service, has been running optimally, regularly and guided by mutually determined goals. This is also in accordance with the opinion of Henry Fayol in the book Inu Kencana Syafii (2011:34) that regular synchronization coordination of efforts to create guided time management results in harmonious and unified implementation results to produce goals that have been set

\section{Common interests}

Research findings from the results of the interview that the Gunung Mas District Disaster Management Agency has assigned and Disaster Alert Officers whose duties include providing information quickly and accurately on current or already occurring disasters. This information was given to the Rapid Response Team (TRC) of the Management Gunung Mas District DisasterAgency. The team quickly responds to the information provided by coordinating with other relevant agencies as well as inspecting the disaster location and quickly listing what is needed for the victims of the disaster. Common interests are an essential element in coordination so that there is a comprehensive view of achieving common goals. The mutual interest in disaster management in Gunung Mas Regency which is written in the law is the basis for the achievement of the Gunung Mas District Disaster Management Agency in disaster management for the provision of logistics and equipment. 
Based on the research and interview results, it can be seen that the coordination is carried out so that the goals can be achieved as targeted. Coordination between agencies in disaster management in the Gunung Mas Regency area is carried out in stages, namely horizontally and vertically, namely coordination with direct supervisors by the line of command or with other Agencies that have the same functions. The Regional Disaster Management Agency of Gunung Mas Regency is a managerial role in the coordination which involves cross-sectoral, cross, and cross-disciplinary in a directed and integrated and comprehensive manner. The Regional Secretary as the Head of the Regional Disaster Management Agency has a high managerial level in disaster management because hierarchically, he is the centre in coordinating and equating all understanding with other related institutions, both the Social Service and other institutions as well as carrying out orders directly to the Management Agency. Regional Disasters and other agencies in terms of management disaster.

The findings in the field show that the shared interests of some other related institutions or agencies as well as in particular the Gunung Mas Regency Government are the essential elements in the coordination which carried out by the Gunung Mas District Disaster Management Agency has focused on the same goal of creating a unity of action in the prevention disaster that is by the opinion expressed by James D. Mooney in the book Inu Kencana Syafiie (2011: 34) that coordination is an orderly arrangement of group efforts, to create unity of action in pursuit of common goals. However, this is also not by Endah Mustika Ramdani's research (2015) that the role of the coordinator has not been going well because there are still different perceptions of actors management disaster. There are still many other related institutions that have not adapted to the role of the Regional Disaster Management Agency of Gunung Mas Regency. as coordinator and commando in disaster management.

\section{Common Goals}

Coordination in regional disaster management in the Gunung Mas Regency Region, namely internal coordination with the local Regional Government, coordination with related institutions, with the community as well as with disaster preparedness officers in each village in the Gunung Mas Regency Area so that handling disaster handled effectively and efficiently. Based on the results of interviews with researchers, it was found that the common goal in disaster management is the process of bringing together the agreed objectives between the Gunung Mas District Disaster Management Agency and the Gunung Mas District Social Service and other institutions to achieve common goals in disaster management in the Gunung Mas district. Mas and this is by the opinion of Stoner \& Freeman (1992: 322) states that coordination as coordination is the process of integrating the goals and activities of the units or parts of a separate organization to provide a unity of action to achieve goals together.

The findings of the researchers also show that to achieve common goals so that disaster management can be handled quickly, the Regional Disaster Management Agency, in particular the Rapid Response Team (TRC), always communicates continuously with disaster preparedness officers in each village in the Gunung Regency Region. Mas. One of the main tasks of disaster preparedness officers is to report every disaster incident to the Regional Disaster Management Agency of Gunung Mas Regency. The findings of the researchers also show that the common goal of the Gunung Mas Regional Disaster Management Agency in disaster management is to handle disaster events and to provide logistics and equipment for disaster victims and this has been carried out quite well.

\section{The inhibiting factor for coordination}


Factors hindering the coordination of the Gunung Mas District Disaster Management Agency in providing logistics and equipment for disaster management in Gunung Mas District, Central Kalimantan Province, including :

\section{Obstacles in vertical/structural coordination.}

In management disaster in Gunung Mas Regency, good coordination is needed. The Head of the Regional Disaster Management Agency for Gunung Mas Regency has a function as a command over management disaster, institutions and other agencies related to disaster management in the formulation of tasks, authorities and responsibilities that are still lacking. The function of the Gunung Mas District Disaster Management Agency is to carry out disaster management in a planned, integrated and comprehensive manner. Other related institutions still do not understand the vital role and unique role and regulations of disaster management, especially in understanding the position of the Gunung Mas Regional Disaster Management Agency as the leading sector in disaster management, resulting in less than optimal disaster management.

Lack of understanding of each service unit, agency or other institution regarding the existence of work relations and work procedures and procedures and the critical role of the Gunung Mas District Disaster Management Agency in disaster management is an obstacle to the disaster management process in Gunung Mas Regency. Role of Social Service Gunung Mas in the provision of logistics should always consult and coordinate with the Regional Disaster Management Agency Gunung Mas to avoid the supply and distribution logistics that overlap or are not well targeted, resulting in less inequality in distribution conducted. Community participation is needed in disaster management. The community is expected to take an active role in disaster management. However, this is poorly understood because people feel that disaster management is the role of the government. This results in a lack of community contribution to disaster management.

\section{Barriers to functional coordination.}

In coordinating the obstacles experienced by the Gunung Mas Regional Disaster Management Agency, namely not having a hierarchical relationship (line of command) due to different work units because what is the binder between these work units is that each has the same duties and functions, but in providing logistics and disaster management equipment The Regional Disaster Management Agency of Gunung Mas Regency still has limitations in terms of logistics, equipment and funds, therefore it is necessary to harmonize and synchronize cooperation between institutions that have the same work function because the Regency Regional Disaster Management Agency Gunung Mas would not have been able to carry out its duties and functions without the support and assistance of other institutions that have essential functions and roles in disaster management. Different command lines of the Gunung Mas District Disaster Management Agency and the Gunung Mas District Social Service or other services/agencies/units or those that are coordinated and coordinated do not have a hierarchical relationship or are not in the same organizational unit will greatly influence or become an obstacle. Coordination carried out by the Regional Disaster Management Agency of Gunung Mas Regency in terms of disaster management, especially in the provision and distribution of logistics and equipment.

Services/agencies / other institutional units that are not within the line of command of the Gunung Mas Regional Disaster Management Agency become an obstacle in the coordination process carried out by the Gunung Mas District Disaster Management Agency because hierarchically different command lines or their respective work units are causing the coordination and implementation of the countermeasures to be disrupted and hampered. 


\section{CONCLUSION}

The coordination of the Gunung Mas District Disaster Management Agency in providing logistics and equipment for disaster management in Gunung Mas Regency in terms of timing and timeliness, synchronization, shared interests, and common goals has been well-coordinated by the system and pattern as well as the prevailing regulations. The coordination of the Gunung Mas District Disaster Management Agency is limited to providing logistics and equipment for victims of natural and non-natural disasters in Gunung Mas Regency.

The obstacles in the coordination of the Regional Disaster Management Agency in the provision of logistics and equipment for disaster management in Gunung Mas District are strongly influenced by the lack of understanding of other relevant agencies regarding their duties, powers and responsibilities for disaster management. Apart from this, another obstacle is the Regional Disaster Management Agency for Gunung Mas Regency and other agencies, agencies and agencies that do not have a hierarchical relationship (line of command) due to different work units.

\section{REFERENCES}

Atmadilaga, Didi. (1994). Buku Pintar Panduan Penulisan Skripsi, Tesis, Disertasi. Bandung: Pionir Jaya.

Awaluddin Djamin dalam Hasibuan, Malayu S.P (2011). Manajemen Sumber Daya Manusia. Jakarta: PT Bumi Aksara.

Charles Lindblom dalam Alexander (1995: 4)

George, Terry (2006). Prinsip-prinsip Manajemen. Jakarta: Bumi Aksara

Handayaningrat, Soewarno. (1989). Administrasi Pemerintahan dalam Pembangunan Nasional. Jakarta: CV. Haji Massagung.

Moeleong, Lexy J., (2000). Metodologi Penelitian Kualitatif. Bandung: Reka Cipta.

Remaja Rosdakarya. (1997). Metodologi Ilmu Pemerintahan. Jakarta: PT. Reka Cipta. Ndraha, Taliziduhu. (2003). Kybernology (Ilmu Pemerintahan Baru) Jilid 1. Jakarta: PT Rineka Cipta.

Sugiyono. (2011). Metode Penelitian Kombinasi. Bandung: Alfabeta.

Syafiie, Inu Kencana (2011). Manajemen Pemerintahan. Bandung: Pustaka Reka Cipta

Adi Hartono (2016) Koordinasi antar Lembaga dan Stakeholder dalam Pengembangan Taman Bacaan Masyarakat ( Studi Kasus : Taman Flora dan Taman Ekspresi di kota Surabaya). Surabaya:

Deasy Ariyanto. (2018). Koordinasi Kelembagaan dalam Meningkatkan Efektivitas Badan Penanggulangan Bencana Daerah. Jakarta:

Endah Mustika Ramdani (2015). PNS STIA LAN Bandung 2015 Koordinasi oleh Badan Penanggulangan Bencana Daerah dalam penanggulangan bencana banjir di Kabupaten Bandung. Bandung:

UU No. 24 Tahun 2007 Tentang Penanggulangan Bencana ( Lembaran Negara Republik Indonesia Tahun 2007 No. 66, Tambahan Lembaran Negara Republik Indonesia Nomor 4723.

Undang-Undang Nomor 32 Tahun 2004 tentang Pemerintah Daerah

Peraturan Pemerintah Nomor 21 Tahun 2008 Tentang Penyelenggaraan Penanggulangan Bencana ( Lembar Negara Republik Indonesia Tahun 2008 No. 42, Tambahan Lembaran Negara Nomor 4829 );

Peraturan Menteri Dalam Negeri Nomor 46 Tahun 2008 tentang Pedoman Organisasi dan Tata Kerja Badan Penanggulangan Bencana Daerah;

Peraturan Kepala BNPB Nomor 3 Tahun 2008 Tentang Pedoman Pembentukan Badan Penanggulangan Bencana Daerah; 
12

Peraturan Daerah Kabupaten Gunung Mas Nomor 8 Tahun 2010, tentang Pembentukan Organisasi dan Tata Kerja Badan Penanggulangan Bencana Daerah Kabupaten Gunung Mas. 